\title{
PERAN EFIKASI DIRI (SELF EFFICACY) DAN KEMAMPUAN BERPIKIR POSITIF TERHADAP KEMAMPUAN PEMECAHAN MASALAH MATEMATIKA
}

\author{
RAHMAWATI YULIYANI \\ rhmwtyuliani@gmail.com \\ Universitas Indraprasta PGRI \\ SHINTA DWI HANDAYANI \\ Universitas Indraprasta PGRI \\ SOMAWATI \\ Universitas Indraprasta PGRI
}

\begin{abstract}
Abstrak.Penelitian ini dilakukam dengan tujuan mengetahui pengaruh efikasi diri (sel efficacy) dan kemampuan berpikir positif terhadap kemampuan pemecahan masalah matematika. Hipotesis penelitian ini meliputi: 1) Terdapat pengaruh langsung efikasi diri (sel efficacy) terhadap kemampuan pemecahan masalah matematika. 2) Terdapat pengaruh langsung kemampuan berpikir positif terhadap kemampuan pemecahan masalah matematika. 3) Terdapat pengaruh langsung efikasi diri (self efficacy) terhadap kemampuan berpikir positif. 4) Terdapat pengaruh tidak langsung efikasi diri (self efficacy) terhadap kemampuan pemecahan masalah melalui berpikir positf. Metode yang digunakan dalam penelitian ini adalah metode survey dan pengujian hipotesis menggunakan teknik analisis jalur (path analysis). Besar sample sebanyak 60 siswa, dengan teknik sampling yang digunakan adalah teknik gabungan antara proporsional dan random, di ambil dari 3 sekolah swasta. Instrumen penelitian yang digunakan yaitu angket efikasi diri (self efficacy) diri sebanyak 30 pernyataan, angket berpikir positif sebanyak 40 pernyataan, tes kemampuan pemecahan masalah berbentuk esaisebanyak 10 soal, yang telah di uji validitasnya.. Hasil pengujian hipotesis menunjukan bahwa: 1) Terdapat pengaruh langsung yang signifikan efikasi diri (sel efficacy) terhadap kemampuan pemecahan masalah matematika. 2) Terdapat pengaruh langsung yang signifikan kemampuan berpikir positif terhadap kemampuan pemecahan masalah matematika. 3) Terdapat pengaruh langsung yang signifikan efikasi diri (self efficacy) terhadap kemampuan berpikir positif. 4) Terdapat pengaruh tidak langsung yang signifikan efikasi diri (self efficacy) terhadap kemampuan pemecahan masalah melalui berpikir positf.
\end{abstract}

Kata Kunci: Efikasi Diri (Self Efficacy), Kemampuan Berpikir Positif, Kemampuan Pemecahan Masalah Matematika.

\begin{abstract}
This research was conducted with the purpose of knowing the influence of self efficacy and positive thinking towards problem solving ability in mathematics. The hypothesis of this research include: 1) there is a direct influence of self efficacy against mathematical problem solving ability. 2) there is a direct influence ability of positive thinking towards problem solving ability in mathematics. 3) there is a direct influence of self efficacy against the ability of positive thinking. 4) there is an indirect influence self efficacy against the ability of problem solving through positive thinking. The methods used in this research is a survey method and hypothesis testing using path analysis. Large sample as many as 60 students, with a sampling technique used was a combination of proportional and random, taken from the three high schools. The research instrument used
\end{abstract}


is self efficacy of 30 statements, positive thinking of 40 statements, test problem solving skills in the form of essays as many as 10 questions, which have been tested the validity. The results of hypothesis testing indicate that: 1) there is a significant direct influence self efficacy against the ability of mathematical problem solving. 2) there is a significant direct influence ability of positive thinking towards problem solving ability in mathematics. 3) there is a significant direct influence self efficacy against the ability of positive thinking. 4) there is a significant indirect influence efficacy of self against the ability of problem solving through positive thinking.

Keywords: Self Efficacy, Positive Thinking Ability, Mathematical Problem Solving Ability

\section{PENDAHULUAN}

Kurikulum untuk mata pelajaran matematika berubah seiring dengan perkembangan kurikulum yang berlaku. Permendiknas nomor 22 tahun 2006 dijelaskan bahwa salah satu tujuan pembelajaran matematika di sekolah adalah memecahkan masalah yang meliputi memahami masalah, merancang model matematika, menyelesaikan model, dan menafsirkan solusi. Kemampuan pemecahan masalah matematika merupakan bagian dari kurikulum matematika yang sangat penting karena dalam proses pembelajaran maupun penyelesaian, siswa dimungkinkan memperoleh pengalaman menggunakan pengetahuan serta keterampilan yang sudah dimiliki untuk diterapkan pada pemecahan masalah yang tidak rutin. Pemecahan masalah meliputi memahami masalah, merancang pemecahan masalah, menyelesaikan masalah, memeriksa hasil kembali. Karena itu pemecahan masalah merupakan suatu tingkat aktivitas intelektual yang tinggi, serta siswa didorong dan diberi kesempatan seluas-luasnya untuk berinisiatif dan berfikir sistematis dalam menghadapi suatu masalah dengan menerapkan pengetahuan yang didapat sebelumnya. Namun kemampuan pemecahan masalah siswa masih belum cukup memuaskan, hal ini sejalan dengan hasil penelitian Prasetyo \& Haryanto (dalam Leonard, 2015: 137) secara umum hasil kemampuan tentang pemecahan masalah matematik siswa belum memuaskan dengan nilai rata rata di angka 68,5.

Faktor-faktor yang menyebabkan timbulnya masalah-masalah dalam pembelajaran matematika antara lain masih banyaknya siswa beranggapan bahwa pelajaran matematika adalah pelajaran yang sukar dan biasanya belajar matematika memerlukan konsentrasi tinggi. Mereka menganggap matematika suatu pelajaran yang menakutkan, membosankan, dan menjadi beban bagi siswa karena bersifat abstrak, penuh dengan angka dan rumus. Selain itu, masih adanya sistem belajar yang menyamaratakan kemampuan siswa. Saat siswa belum menguasai materi dasar, sudah ditambah dengan materi lain. Para siswa pun cenderung tidak menyukai matematika karena dianggap sulit terutama dalam menyelesaikan soal-soal yang diberikan oleh guru matematika.

Menyikapi hal seperti ini di harapkan siswa mampu mengembangkan kemampuannya, agar pencepaian prestasi akademik dapat optimal. Untuk itu, individu sebagai siswa selayaknya memiliki keyakinan dalam dirinya. Salah satu keyakinan diri seseorang mengenai kemampuan atau kecakapannya untuk melakukan tugas akademik adalah dengan efikasi diri. Efikasi diri akademik mengacu pada keyakinan yang berkaitan dengan kemampuan dan kesanggupan seorang pelajar untuk mencapai dan menyelesaikan tugas-tugas studi dengan target hasil dan waktu yang telah ditentukan. Efikasi diri akademik mengacu pada pertimbangan seberapa besar keyakinan seseorang tentang kemampuannya melakukan sejumlah aktivitas belajar dan kemampuannya menyelesaikan tugas-tugas belajar. 
Efikasi diri akademik sangat penting bagi pelajar untuk mengontrol motivasi mencapai harapan-harapan akademik. Efikasi diri akademik jika disertai dengan tujuantujuan yang spesifik dan pemahaman mengenai prestasi akademik, maka akan menjadi penentu suksesnya perilaku akademik di masa yang akan datang. Namun efikasi diri yang dimiliki setiap siswa pasti berbeda, perbedaan ini di dasarkan pada tingkat keyakinan dan kemampuan setiap siswa. Siswa yang memiliki efikasi diri yang baik akan berhasil dalam kegiatan belajarnya dan dapat melakukan tugas-tugas akademiknya dengan lancar. Berbeda jika efikasi yang dimiliki siswi rendah maka siswa akan cepat menyerah pada setiap permasalahan yang di hadapi.

Dalam hal ini peneliti melihat terdapat gejala dimana siswa tidak memiliki pikiran yang positif dalam belajar matematika ataupun mengerjakan tugas, siswa seharusnya memiliki pikiran yang positif agar siswa bisa selalu percaya dan yakin dengan apa yang dikerjakan, siswa seharusnya memiliki pikiran yang positif agar siswa bisa selalu percaya dan yakin dengan apa yang dikerjakan. Menurut Adelia (2011:68) berpikir positif adalah pikiran yang dapat membangun dan memperkuat kepribadian atau karakter. Ini juga berarti bahwa dengan berpikir positif seseorang bisa menjadi pribadi yang matang, serta lebih berani dalam menghadapi tantangan. Setiap pemikir positif akan melihat setiap kesulitan dengan cara yang gamblang dan polos serta tidak mudah terpengaruh sehingga menjadi putus asa oleh berbagai tantangan ataupun hambatan yang dihadapi. Individu yang berpikir positif selalu didasarkan fakta bahwa setiap masalah pasti ada pemecahan dan suatu pemecahan yang tepat selalu melalui proses intelektual yang sehat.

Berdasarkan paparan di atas, maka penulis merasa perlu untuk meneliti dengan tujuan untuk menemukan secara empiris tentang pengaruh variabel efikasi diri (self efficacy) dan kemampuan perpikir positif terhadap kemampuan pemecahan masalah matematika.

\section{TINJAUAN PUSTAKA}

\section{Kemampuan Pemecahan Masalah Matematika}

Pemecahan masalah adalah proses menerapkan pengetahuan yang telah diperoleh sebelumnya kedalam situasi baru yang belum dikenal. Untuk menjadi seorang pemecah masalah yang baik, siswa membutuhkan banyak kesempatan untuk menciptakan dan memecahkan masalah dalam bidang matematika dan dalam konteks kehidupan nyata.

Sumarmo (2005:21) mengartikan pemecahan masalah sebagai kegiatan menyelesaikan soal cerita, menyelesaikan soal yang tidak rutin, mengaplikasikan matematika dalam kehidupan sehari-hari atau keadaan lain, dan membuktikan atau menciptakan atau menguji konjektur. Berdasarkan pengertian yang dikemukakan Sumarmo tersebut, dalam pemecahan masalah matematika tampak adanya kegiatan pengembangan daya matematika (mathematical power) terhadap siswa.

Ruseffendi (2006:336) mengemukakan bahwa suatu soal merupakan soal pemecahan masalah bagi seseorang bila ia memiliki pengetahuan dan kemampuan untuk menyelesaikannya, tetapi pada saat ia memperoleh soal itu ia belum tahu cara menyelesaikannya. Dalam buku yang sama Ruseffendi (2006:337) juga mengemukakan bahwa suatu persoalan itu merupakan masalah bagi seseorang jika: pertama, persoalan itu tidak dikenalnya. Kedua, siswa harus mampu menyelesaikannya, baik kesiapan mentalnya maupun pengetahuan siapnya; terlepas daripada apakah akhirnya ia sampai atau tidak kepada jawabannya. Ketiga, sesuatu itu merupakan pemecahan masalah baginya, bila ia ada niat untuk menyelesaikannya. Tuntutan akan kemampuan pemecahan masalah dipertegas secara eksplisit dalam kurikulum saat ini yaitu kurikulum 2013, sebagai dasar yang harus dikembangkan dan di ntegrasikan pada sejumlah materi tertentu. Pandangan pemecahan masalah sebagai proses inti dan utama dalam kurikulum 
matematika, berarti pembelajaran pemecahan masalah lebih mengutamakan proses dan strategi yang dilakukan siswa dalam menyelesaikannya dari pada hanya sekedar hasil sehingga keterampilan prosesdan strategi dalam memecahkan masalah tersebut menjadi kemampuan dasar dalam belajar matematika.

Dari berbagai pengertian yang telah diutarakan di atas maka penulis dapat mengambil kesimpulan bahwa pemecahan masalah matematika adalah upaya mencari jalan keluar yang dilakukan dalam mencapai tujuan. Juga memerlukan kesiapan, kreativitas, pengetahuan dan kemampuan serta aplikasinya dalam kehidupan sehari-hari. Di samping itu pemecahan masalah merupakan persoalan-persoalan yang belum dikenal, serta mengandung pengertian sebagai proses berfikir tinggi dan penting dalam pembelajaran matematika.

\section{Efikasi Diri (Self Efficacy)}

Keyakinan diri seseorang mengenai kemampuan atau kecakapannya untuk melakukan tugas akademik yang diberikan disebut efikasi diri akademik. Bandura (Taylor, S.E. Peplau, L.T. Sears, D.O, 2009) mengemukakan bahwa peran efikasi diri sebagai mekanisme yang mendasari perubahan perilaku, pemeliharaan dan generalisasi. Perubahan perilaku terjadi setelah ada kegiatan pembelajaran siswa. Pada awal kegiatan pembelajaran, masing-masing siswa mempunyai tingkat keyakinan dan kemampuan yang berbeda. Perbedaan tingkat keyakinan tersebut berdasarkan pengalaman sebelumnya misalnya pemahaman materi pelajaran sebelumnya, tingkat kecerdasannya dan sikapnya dalam mengikuti kegiatan pembelajaran. Siswa yang mempunyai efikasi diri yang baik akan berhasil dalam kegiatan belajarnya dan dapat melakukan tugas-tugas akademiknya dengan lancar.

Park dan Kim (2006:276) menjelaskan efikasi diri akademik sangat penting bagi pelajar untuk mengontrol motivasi mencapai harapan-harapan akademik. Efikasi diri akademik jika disertai dengan tujuan-tujuan yang spesifik dan pemahaman mengenai prestasi akademik, maka akan menjadi penentu suksesnya perilaku akademik di masa yang akan datang.Selanjutnya menurut Baron dan Byrne (2003:183), efikasi diri akademik dapat diartikan sebagai keyakinan seseorang bahwa dirinya mampu untuk melakukan tugas akademik yang diberikan dan menandakan level kemampuan dirinya.

Ada dua tipe efikasi diri yang ada dalam diri seseorang yang 1) efikasi diri akademik yang rendah dengan ciri-ciri selalu menjauhi tugas-tugas yang sulit, berhenti dengan cepat bila menemui kesulitan, memiliki cita-cita yang rendah dan komitmen yang buruk untuk tujuan yang telah dipilih, berfokus pada akibat yang buruk dari kegagalan, cenderung mengurangi usaha karena lambat memperbaiki keadaan dari kegagalan yang dialami, mudah mengalami stres dan depresi. 2) efikasi diri akademik yang tinggi dengan ciri-ciri: mendekati tugas-tugas yang sulit sebagai tantangan untuk dimenangkan, menyusun tujuan-tujuan yang menantang dan memelihara komitmen untuk tugas-tugas tersebut, mempunyai usaha yang tinggi atau gigih, memiliki pemikiran strategis, berpikir bahwa kegagalan yang dialami karena usaha yang tidak cukup sehingga diperlukan usaha yang tinggi dalam menghadapi kesulitan.

Dari berbagai pengartian yang telah diutarakan di atas maka penulis dapat mengambil kesimpulan bahwa efikasi diri (self efficacy) adalah keyakinan seseorag terhadap kemampuannya dalam mengatasi beraneka ragam situasi yang muncul dalam hidupnya. Efikasi diri jika disertai dengan tujuan-tujuan yang spesifik dan pemahaman mengenai prestasi akademik, maka akan menjadi penentu suksesnya perilaku akademik di masa yang akan datang. Efikasi diri yang dimiliki setiap siswa berbeda, perbedaan ini di dasarkan pada tingkat keyakinan dan kemampuan setiap siswa. Siswa yang memiliki efikasi diri yang baik akan berhasil dalam kegiatan belajarnya dan dapat melakukan 
tugas-tugas akademiknya dengan lancar. Berbeda jika efikasi yang di miliki siswi rendah maka siswa akan cepat menyerah pada setiap permasalahan yang dihadapi.

\section{Kemampuan Berpikir Positif}

Manusia merupakan makhluk hidup yang memiliki kemampuan paling baik. Salah satu kemampuan manusia yang tidak dimiliki oleh makhluk hidup yang lain adalah kemampuan berpikir. Dari berbagai kemampuan yang ada pada manusia, berpikir merupakan kemampuan yang memegang peranan penting dalam menentukan kualitas hidupnya. Namun demikian tidak setiap orang mampu mengoptimalkan peran kemampuan ini. Salah satu usaha yang mestinya dilakukan agar pikiran bisa berperan secara baik adalah belajar untuk berpikir positif.

Berpikir positif terbentuk dari kebiasaan berpandangan positif, atau memiliki persepsi untuk memandang segala sesuatu selalu pada sisi baiknya. Hal ini sejalan dengan yang di kemukakan Arifin (2010:19) mengatakan berpikir positif adalah aktivitas berpikir yang kita lakukan dengan tujuan untuk membangun dan membangkitkan aspek positif pada diri kita, baik itu yang berupa potensi, spirit (semangat), tekad, maupun keyakinan diri kita. Elfiky (2009:269) menyebutkan saat seseorang berpikir, informasi yang dipikirkannya akan dimaknai dan pada akhirnya memanifestasikan perasaan tertentu. Oleh sebab itu berpikir positif pada hakikatnya juga berkaitan erat dengan emosi.

Dari berbagai pengartian yang telah diutarakan di atas maka penulis dapat mengambil kesimpulan bahwa kemampuan berpikir positif adalah sikap atau perilaku yang dimiliki untuk mengembangkan cara menentukan pilihan dengan menggunakan akal pikiran sehat dan jernih yang bersumber atau timbul dari energi positif dan juga memandang segala sesuatu dari segi kebaikannya, sehingga menghasilkan pandangan seorang individu dan kepribadian individu seseorang yang baik terhadap dirinya sendiri, orang lain yang saling berhubungan, dan keluara serta lingkungan.

\section{METODE}

Penelitian ini merupakan penelitian survey dengan pendekatan kuantitatif, dimana peneliti menggambarkan fenomena yang terjadi berdasarkan data yang diambil dari responden menggunakan instrument yang telah divalidasi sebelumnya. Penelitian ini diadakan diwilayah sekecamatan Jagakarsa jeenjang pendidikan yang diteliti adalah Sekolah Mengah Atas. Teknik sampling yang digunakan adalah gabungan antara proporsional dan random. Dalam menentukan jumlah anggotasampel dari setiap sekolah digunakan teknik proporsional, sedangkan untuk menentukan anggota sampel dari setiap sekolah dipilih secara acak. Jumlah anggota sampelnya adalah 60 siswa.

Data yang digunakan adalah instrument yang sebelunya divalidasi, yaitu: instrume untuk mengukur Effikasi Diri (Self Efficacy) (terbagi dalam indikator magnitude, strength, dan generality) dengan jumlah 30 butir pernyataan, Berpikir Positif (terbagi dalam indicator harapan yang positif, affirmasi diri, pernyataan yang tidak menilai, penyesuaian diri yang realistic) dengan jumlah 40 butir pernyataan dan Pemecahan Masalah Matematika (terbagi dalam indikator mendeskripsikan kaidah pencacahan, permutasi, dan kombinasi serta menghitung peluang suatu kejadian) dengan jumlah 10 butir soal esai.

Selanjutnya instrument yang sudah divalidasi tersebut disebarkan kepada responden, untuk kemudian hasilnya ditabulasi dan dianalisis. Data yang telah diperoleh selanjutnya diuji persyaratan analisis datanya, yaitu uji normalitas dan uji linieritas, kemudian selanjutnya selanjutnya diadakan uji hipotesis, dimana analisis data yang digunakan adalah analisis jalur (path analysis). 
Keterangan:

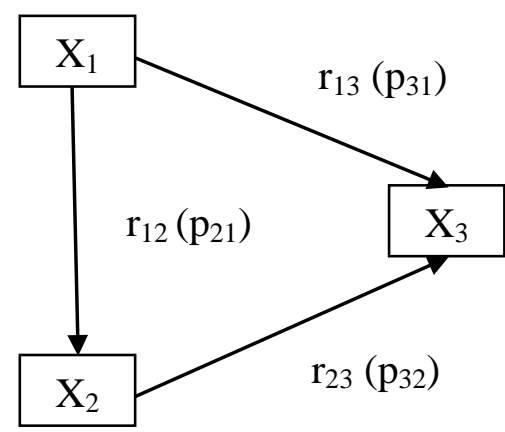

Gambar 1. Desain Penelitian

$\mathrm{X}_{1}$ : Efikasi Diri (Self Efficacy)

$\mathrm{X}_{2}$ : Berpikir Positif

$\mathrm{X}_{3}$ : Kemampuan Pemecahan Masalah

\section{HASIL DAN PEMBAHASAN}

\section{Analisis Deskriptif}

Data yang telah dikumpulkan kemudian ditampilkan secara deskriptif dalam tabel 1 .

Tabel 1. Deskripsi data tiap variabel

\section{Statistics}

\begin{tabular}{|c|c|c|c|c|}
\hline & & Efikasi_Diri & Berpikir_Positif & $\begin{array}{c}\text { Pemecahan_Masalah_Mat } \\
\text { ematika }\end{array}$ \\
\hline \multirow[t]{2}{*}{$\mathrm{N}$} & Valid & 60 & 60 & 60 \\
\hline & Missing & 0 & 0 & 0 \\
\hline \multicolumn{2}{|c|}{ Mean } & 116.83 & 98.60 & 67.75 \\
\hline \multicolumn{2}{|c|}{ Median } & 117.00 & 98.00 & 68.00 \\
\hline \multicolumn{2}{|c|}{ Mode } & 117 & $96^{\mathrm{a}}$ & 68 \\
\hline \multicolumn{2}{|c|}{ Std. Deviation } & 11.007 & 11.939 & 2.989 \\
\hline \multicolumn{2}{|c|}{ Variance } & 121.158 & 142.549 & 8.936 \\
\hline \multicolumn{2}{|c|}{ Range } & 40 & 48 & 12 \\
\hline \multicolumn{2}{|c|}{ Minimum } & 97 & 76 & 62 \\
\hline \multicolumn{2}{|c|}{ Maximum } & 137 & 124 & 74 \\
\hline \multicolumn{2}{|c|}{ Sum } & 7010 & 5916 & 4065 \\
\hline
\end{tabular}

a. Multiple modes exist. The smallest value is shown

Dari tabel 1. tergambar bahwa secara deskriptif, efikasi diri (self efficacy) responden tergolong baik, hal ini terlihat dari nilai modus berada diatas rata-rata. Kemampuan berpikir positif tergolong dalam katagori cukup, hal ini terlihat dari nilai modus yang hanya sedikit lebih kecil dibandingkan dengan rata-rata dan kemampuan pemecahan masalah matematika memiliki kecenderungan positif, terlihat dari nilai modus dan median diatas rata-rata, walaupun skor keseluruhan yang kecil. 


\section{Pengujian Persyaratan Analisis}

Tabel 2. Hasil Uji Normalitas

One-Sample Kolmogorov-Smirnov Test

\begin{tabular}{|c|c|c|c|c|}
\hline & & $\begin{array}{l}\text { Efikasi } \\
\text { Diri }\end{array}$ & $\begin{array}{l}\text { Berpikir } \\
\text { Positif }\end{array}$ & $\begin{array}{c}\text { Pemecahan Masalah } \\
\text { Matematika }\end{array}$ \\
\hline $\bar{N}$ & & 60 & 60 & 60 \\
\hline \multirow[t]{2}{*}{ Normal Parameters ${ }^{\mathrm{a}, \mathrm{b}}$} & Mean & 116.83 & 98.60 & 67.75 \\
\hline & $\begin{array}{l}\text { Std. } \\
\text { Deviation }\end{array}$ & 11.007 & 11.939 & 2.989 \\
\hline \multirow[t]{3}{*}{ Most Extreme Differences } & Absolute & .106 & .087 & .083 \\
\hline & Positive & .097 & .087 & .083 \\
\hline & Negative & -.106 & -.052 & -.067 \\
\hline Test Statistic & & .106 & .087 & .083 \\
\hline Asymp. Sig. (2-tailed) & & $.091^{\mathrm{c}}$ & $.200^{\mathrm{c}, \mathrm{d}}$ & $.200^{\mathrm{c}, \mathrm{d}}$ \\
\hline
\end{tabular}

a. Test distribution is Normal.

Dari tabel 2 hasil perhitungan dengan menggunakan SPPS di atas, terlihat bahwa nilai signifikasi secara keseluruhan $>0,05$, sehingga dapat dikatakan bahwa data berdistribusi normal.

Tabel 3. Hasil Pengujian Linieritas Hubungan Variabel $X_{1}$ dengan $X_{3}$

\begin{tabular}{|c|c|c|c|c|c|c|c|}
\hline \multicolumn{8}{|c|}{ ANOVA Table } \\
\hline & & & $\begin{array}{c}\text { Sum of } \\
\text { Square } \\
\text { s }\end{array}$ & $\mathrm{df}$ & $\begin{array}{l}\text { Mean } \\
\text { Square }\end{array}$ & $\mathrm{F}$ & Sig. \\
\hline \multirow{7}{*}{$\begin{array}{l}\text { Pemecahan } \\
\text { Masalah } \\
\text { Matematika * } \\
\text { Efikasi_Diri }\end{array}$} & \multirow{5}{*}{$\begin{array}{l}\text { Between } \\
\text { Groups }\end{array}$} & (Combined) & 511.74 & & 63968 & 210.3 & 000 \\
\hline & & & 0 & 8 & 03.908 & 45 & .000 \\
\hline & & Linearity & 509.00 & & 509.00 & 1673. & 000 \\
\hline & & & 8 & 1 & 8 & 771 & .000 \\
\hline & & $\begin{array}{l}\text { Deviation from } \\
\text { Linearity }\end{array}$ & 2.733 & 7 & .390 & 1.284 & .277 \\
\hline & \multirow{2}{*}{\multicolumn{2}{|c|}{$\begin{array}{l}\text { Within Groups } \\
\text { Total }\end{array}$}} & 15.510 & 51 & .304 & & \\
\hline & & & $\begin{array}{r}527.25 \\
0\end{array}$ & 59 & & & \\
\hline
\end{tabular}

Dari tabel 3. terlihat nilai pada kolom Sig baris deviation from linierity $=0,277$ lebih dari 0,05. Dengan kata lain bahwa garis regresi hubungan efikasi diri (self efficacy) $\left(X_{1}\right)$ dengan pemecahan masalah matematika $\left(X_{3}\right)$ linier. 
Tabel 4. Hasil Pengujian Linieritas Hubungan Variabel $\mathrm{X}_{2}$ dengan $\mathrm{X}_{3}$

\begin{tabular}{|c|c|c|c|c|c|c|c|}
\hline \multicolumn{8}{|c|}{ ANOVA Table } \\
\hline & & & $\begin{array}{l}\text { Sum of } \\
\text { Squares }\end{array}$ & $\mathrm{df}$ & $\begin{array}{l}\text { Mean } \\
\text { Square }\end{array}$ & $\mathrm{F}$ & Sig. \\
\hline \multirow{5}{*}{$\begin{array}{l}\text { Pemecahan_M } \\
\text { asalah_Matem } \\
\text { atika* } \\
\text { Berpikir_Posit } \\
\text { if }\end{array}$} & Between & (Combined) & 521.101 & 12 & 43.425 & 331.931 & .000 \\
\hline & Groups & Linearity & 519.866 & 1 & 519.866 & 3973.729 & .000 \\
\hline & & $\begin{array}{l}\text { from } \\
\text { Linearity }\end{array}$ & 1.235 & 11 & .112 & .858 & .585 \\
\hline & Within G & oups & 6.149 & 47 & .131 & & \\
\hline & Total & & 527.250 & 59 & & & \\
\hline
\end{tabular}

Dari tabel 4. terlihat nilai pada kolom Sig baris deviation from linierity $=0,585$ lebih dari 0,05. Dengan kata lain bahwa garis regresi hubungan hubungan berpikir positif $\left(\mathrm{X}_{2}\right)$ dengan pemecahan masalah matematika $\left(\mathrm{X}_{3}\right)$ linier.

Tabel 5. Hasil Pengujian Linieritas Hubungan Variabel $X_{1}$ dengan $X_{2}$

\begin{tabular}{|c|c|c|c|c|c|c|c|}
\hline \multicolumn{8}{|c|}{ ANOVA Table } \\
\hline & & & $\begin{array}{l}\text { Sum of } \\
\text { Squares }\end{array}$ & $\mathrm{df}$ & $\begin{array}{l}\text { Mean } \\
\text { Square }\end{array}$ & F & Sig. \\
\hline \multirow{5}{*}{$\begin{array}{l}\text { Efikasi_Diri } \\
* \\
\text { Berpikir_Posi } \\
\text { tif }\end{array}$} & \multirow{3}{*}{$\begin{array}{l}\text { Between } \\
\text { Groups }\end{array}$} & (Combined) & 6983.452 & 12 & 581.954 & 165.889 & .000 \\
\hline & & Linearity & 6914.757 & 1 & 6914.757 & $\begin{array}{r}1971.08 \\
0\end{array}$ & .000 \\
\hline & & $\begin{array}{l}\text { Deviation from } \\
\text { Linearity }\end{array}$ & 68.695 & 11 & 6.245 & 1.780 & .085 \\
\hline & \multicolumn{2}{|c|}{ Within Groups } & 164.881 & 47 & 3.508 & & \\
\hline & \multicolumn{2}{|l|}{ Total } & 7148.333 & 59 & & & \\
\hline
\end{tabular}

Dari tabel 5. terlihat nilai pada kolom Sig baris deviation from linierity $=0,085$ lebih dari 0,05. Dengan kata lain bahwa garis regresi hubungan efikasi diri (self efficacy) $\left(\mathrm{X}_{1}\right)$ dengan berpikir positif $\left(\mathrm{X}_{2}\right)$ linier

\section{Analisis Korelasi}

Tabel 7. Perhitungan Koefisien Korelasi

\section{Correlations}

\begin{tabular}{|c|c|c|c|c|}
\hline & & Efikasi Diri & $\begin{array}{l}\text { Berpikir } \\
\text { Positif }\end{array}$ & $\begin{array}{l}\text { Pemecahan } \\
\text { Masalah } \\
\text { Matematika }\end{array}$ \\
\hline \multirow[t]{3}{*}{ Efikasi_Diri } & Pearson Correlation & 1 & $.984^{* *}$ & $.983^{* *}$ \\
\hline & Sig. (2-tailed) & & .000 & .000 \\
\hline & $\mathrm{N}$ & 60 & 60 & 60 \\
\hline \multirow[t]{3}{*}{ Berpikir_Positif } & Pearson Correlation & $.984^{* * *}$ & 1 & $.993^{* *}$ \\
\hline & Sig. (2-tailed) & .000 & & .000 \\
\hline & $\mathrm{N}$ & 60 & 60 & 60 \\
\hline \multirow{3}{*}{$\begin{array}{l}\text { Pemecahan_Masalah } \\
\text { _Matematika }\end{array}$} & Pearson Correlation & $.983^{* *}$ & $.993^{* *}$ & 1 \\
\hline & Sig. (2-tailed) & .000 & .000 & \\
\hline & $\mathrm{N}$ & 60 & 60 & 60 \\
\hline
\end{tabular}


**. Correlation is significant at the 0.01 level (2-tailed).

Tabel 9. Koefisien Jalur $p_{21}$

\section{Coefficients $^{\mathrm{a}}$}

\begin{tabular}{|c|c|c|c|c|c|c|}
\hline \multirow[t]{2}{*}{ Model } & & \multicolumn{2}{|c|}{$\begin{array}{c}\text { Unstandardized } \\
\text { Coefficients }\end{array}$} & \multirow{2}{*}{$\begin{array}{c}\text { Standardized } \\
\text { Coefficients } \\
\text { Beta }\end{array}$} & \multirow[t]{2}{*}{$\mathrm{t}$} & \multirow[t]{2}{*}{ Sig. } \\
\hline & & $\mathrm{B}$ & Std. Error & & & \\
\hline \multirow[t]{2}{*}{1} & (Constant) & $1.470 \mathrm{E}-15$ & .024 & & .000 & 1.000 \\
\hline & Zscore(Efikasi_Diri) & .984 & .024 & .984 & 41.437 & .000 \\
\hline
\end{tabular}

a. Dependent Variable: Zscore(Berpikir_Positif)

Tabel 10. Koefisien Jalur $p_{31}$ dan $p_{32}$

Coefficients $^{\mathbf{a}}$

\begin{tabular}{|c|c|c|c|c|c|}
\hline \multirow[t]{2}{*}{ Model } & \multicolumn{2}{|c|}{$\begin{array}{c}\text { Unstandardized } \\
\text { Coefficients } \\
\end{array}$} & \multirow{2}{*}{$\begin{array}{c}\text { Standardized } \\
\text { Coefficients } \\
\text { Beta }\end{array}$} & \multirow[t]{2}{*}{$\mathrm{t}$} & \multirow[t]{2}{*}{ Sig. } \\
\hline & $\mathrm{B}$ & Std. Error & & & \\
\hline 1 (Constant) & $-1.053 \mathrm{E}-14$ & .015 & & .000 & 1.000 \\
\hline Zscore(Efikasi_Diri) & .182 & .083 & .182 & 2.179 & .033 \\
\hline $\begin{array}{l}\text { Zscore(Berpikir_Positif } \\
\text { ) }\end{array}$ & .814 & .083 & .814 & 9.775 & .000 \\
\hline
\end{tabular}

a. Dependent Variable: Zscore(Pemecahan_Masalah_Matematika)

Untuk memeperjelas data di atas, diperoleh hasil seperti terlihat pada analisis jalur dibawah ini:

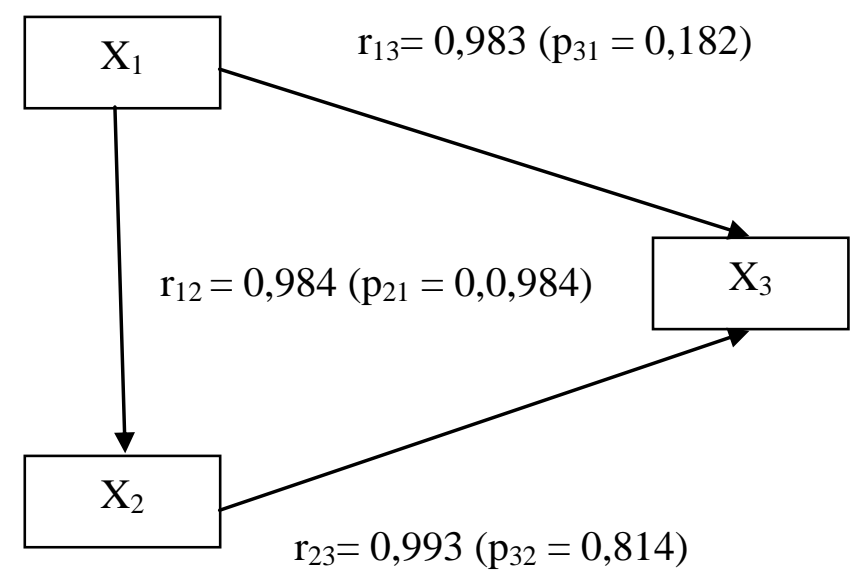

Keterangan:

$\mathrm{X}_{1}=$ Efikasi Diri (Self Efficacy)

$\mathrm{X}_{2}=$ Kemampuan Berpikir Positif

$\mathrm{X}_{3}=$ Pemecahan Masalah Matematika

\section{Pengujian Hipotesis Penelitian}

\section{Pengujian Hipotesis 1}

$\mathrm{H}_{\mathrm{o}}$ :tidak terdapat pengaruh langsung antara efikasi diri (self efficacy) terhadap kemampuan pemecahan masalah. 
$\mathrm{H}_{\mathrm{a}}$ :terdapat pengaruh langsung antara efikasi diri (self efficacy) terhadap kemampuan pemecahan masalah.

Dari diagram diatas terlihat bahwa koefisien korelasi antara $X_{I}$ dan $X_{3}$ sebesar 0,983 dan koefisien pengaruh $\mathrm{p}_{31}=0,182$. Untuk $\alpha=0,05$ dan $d k=n-k-1=$ $60-2-1=57$ pada uji dua pihak diperoleh nilai $\mathrm{t}_{\text {tabel }}=\mathrm{t}_{\mathrm{t}}=2,000$.Karena nilai $t_{h}>t_{t}(2,719>2,000)$ maka $\mathrm{H}_{\mathrm{a}}$ diterima dan disimpulkanterdapat pengaruh langsung efikasi diri (self efficacy) terhadap pemecahan masalah matematika.

2. Pengujian Hipotesis 2

$\mathrm{H}_{\mathrm{o}}$ :tidak terdapat pengaruh langsung antara berpikir positif terhadap pemecahan masalah matematika.

$\mathrm{H}_{\mathrm{a}}$ : terdapat pengaruh langsung antara berpikir positif terhadap pemecahan masalah matematika

Dari diagram diatas terlihat bahwa koefisien korelasi antara $X_{2}$ dan $X_{3}$ sebesar 0,993 dan koefisien pengaruh $\mathrm{p}_{32}=0,814$. Untuk $\alpha=0,05$ dan $d k=n-k-1=$ $60-2-1=57$ pada uji dua pihak diperoleh nilai $t_{\text {tabel }}=t_{t}=2,000$. Karena nilai $t_{h}>t_{t}(9,775>2,000)$ maka $\mathrm{H}_{\mathrm{a}}$ diterima dan disimpulkan terdapat pengaruh langsung berpikir positif terhadap pemecahan masalah matematika

\section{Pengujian Hipotesis 3}

$\mathrm{H}_{\mathrm{o}}$ :tidak terdapat pengaruh langsung antara efikasi diri (self efficacy) terhadap berpikir positif.

$\mathrm{H}_{\mathrm{a}}$ : terdapat pengaruh langsung antara efikasi diri (self efficacy) terhadap berpikir positif

Dari diagram diatas terlihat bahwa koefisien korelasi antara $X_{1}$ dan $X_{2}$ sebesar 0,984 dan koefisien pengaruh $\mathrm{p}_{21}=0,984$. Untuk $\alpha=0,05$ dan $d k=n-k-1=$ $60-1-1=58$ pada uji dua pihak diperoleh nilai $t_{\text {tabel }}=t_{t}=2,000$.Karena nilai $t_{h}>t_{t}(41,437>2,000)$ maka $\mathrm{H}_{\mathrm{a}}$ diterima dan disimpulkan terdapat pengaruh langsung efikasi diri (self efficacy) terhadap berpikir positif.

\section{Pengujian Hipotesis 4}

$\mathrm{H}_{\mathrm{o}}$ :tidak terdapat pengaruh tidak langsung efikasi diri (self efficacy) terhadap pemecahan masalah matematika melalui berpikir positif.

$\mathrm{H}_{\mathrm{a}}$ : terdapat pengaruh tidak langsung efikasi diri (self efficacy) terhadap pemecahan masalah matematika melalui berpikir positif.

Dari perhitungan menggunakan Ms Excel didapatkan $t_{\text {hitung }}(13,115)>t_{\text {tabel }}(2,000)$ maka $\mathrm{H}_{\mathrm{a}}$ diterimayang berarti terdapat pengaruh tidak langsung antara efikasi diri (self efficacy) terhadap pemecahan masalah matematika melalui berpikir positif.

\section{Pembahasan}

\section{Pengaruh Langsung Efikasi Diri (Self Efficacy) Terhadap Pemecahan Masalah Matematika}

Temuan penelitian menunjukan bahwa efikasi diri terhadap kemampuan pemecahan masalah matematika memberikan hasil yang signifikan $t_{h}>t_{t}(2,719>$ 2,000 ), walaupun nilainya tidak terlalu besar akan tetapi hal ini membuktikan bahwa ada pengaruh positif dan signifikan antara efikasi diri terhadap kemampuan pemecahan masalah matematika. Dengan kata lain siswa yang memiliki efikasi diri dan persepsi serta cara pandang yang positif tentang dirinya sendiri akan mampu meningkatkan kemampuan pemecahan masalah matematika. Hal ini didukung hasil penelitian yang dilakukan oleh Rezki (2015:427) mengatakan efikasi diri memberikan pengaruh yang signifikan terhadap pemecahan masalah matematika, yang artinya bahwa dalam menyelesaikan pemecahan masalah matematika, semakin tinggi efikasi diri peserta didik maka semakin mudah dalam menyelesaikannya. 
Menurut Baron dan Byrne (2003:183), efikasi diri akademik dapat diartikan sebagai keyakinan seseorang bahwa dirinya mampu untuk melakukan tugas akademik yang diberikan dan menandakan level kemampuan dirinya. Efikasi diri akademik mengacu pada pertimbangan seberapa besar keyakinan seseorang tentang kemampuannya melakukan sejumlah aktivitas belajar dan kemampuannya menyelesaikan tugas-tugas belajar, sehingga sudah seharusnya siswa secara pribadi dapat menumbuhkan efikasi diri yang positif dalam dirinya, serta selaku guru, kepala sekolah, orang tua, dan masyarakat memberikan penghargaan dan apresiasi yang optimal sehingga siswa dapat membangun efikasi diri yang positif.

Berdasarkan temuan penelitian tersebut maka dapat disimpulkan bahwa siswa yang memiliki efikasi diri dan persepsi serta cara pandang yang positif tentang dirinya sendiri akan mampu meningkatkan kemamauan pemecahan masalah matematika.

\section{Pengaruh Langsung Berpikir Positif Terhadap Pemecahan Masalah Matematika}

Temuan penelitian menunjukan bahwa berpikir positif terhadap kemampuan pemecahan masalah matematika memberikan hasil yang signifikan dan menunjukan adanya pengaruh yang cukup tinggi, ini terlihat dari $t_{h}>t_{t}(9,775>2,000)$. Hal ini membuktikan bahwa ada pengaruh yang signifikan antara berpikir positif terhadap kemampuan pemecahan masalah matematika. Dengan kata lain siswa yang memiliki pemikiran yang positif atas kemampuan pada dirinya maka akan meningkatkan kemampuan pemecahan masalah matematika. Hal ini didukung hasil penelitian yang dilakukan oleh Nadun (2015:376) mengatakan kemampuan berpikir positif memberikan pengaruh yang signifikan terhadap pemecahan masalah khususnya dalam pembelajaran matematika.

Kemampuan berpikir positif akan sangat berguna bagi siswa dalam memecahkan masalah dalam pelajaran yang berhubungan dengan soal-soal dan lain sebagainya. Karena kemampuan berpikir positif akan menghindarkan siswa dari pemikiran yang negatif terutama dalam pembelajarn matematika, karena tidak dapat dipungkiri masih banyak siswa yang masih memiliki pemikiran yang negative terhadap pelajaran matematika karena menganggap pelajaran matematika adalah pelajaran yang sulit. Sehingga sangat diperlukannya berpikir positif dalam pemikiran siswa agar siswa selalu terbiasa untuk memandang segala sesuatu selalu pada sisi baiknya. Hal ini sejalan dengan yang di kemukakan Arifin (2010:19) mengatakan berpikir positif adalah aktivitas berpikir yang kita lakukan dengan tujuan untuk membangun dan membangkitkan aspek positif pada diri kita, baik itu yang berupa potensi, spirit (semangat), tekad, maupun keyakinan diri kita.

Berdasarkan temuan penelitian tersebut maka dapat disimpulkan bahwa siswa yang menanamkan pemikiran positif dalam dirinya akan membangun dan membangkitkan aspek positif pada diri siswa dan akan membantunya dalam melihat segala sesuatu dengan positif terutama dalam pembelajaran matematika yang akan mempengaruhinya pada kampuannya dalam pemecahan masalah matematika.

\section{Pengaruh Langsung Efikasi Diri (Self Efficacy) Terhadap Berpikir Positif}

Temuan penelitian menunjukan bahwa efikasi diri terhadap berpikir positif memberikan hasil yang signifikan dan menunjukan adanya pengaruh yang tinggi, ini terlihat dari $t_{h}>t_{t}(41,437>2,000)$. Hal ini membuktikan bahwa ada pengaruh yang signifikan antara efikasi diri terhadap berpikir positif. Dengan kata lain siswa yang memiliki efikasi diri yang tinggi pada dirinya mempengaruhi keyakinan berpikir positif pada siswa. Semakin tinggi efikasi diri siswa maka semakin positif hasil yang didapatkan dan semakin rendah efikasi diri maka kemampuan berpikir positif siswa juga rendah. Hal ini sejalan dengan penelitian Fika Larasati (2015:123) yang mengatakan bahwa terdapat 
hubungan yang positif antara berpikir positif dengan efikasi diri akademik pada mahasiswa yang sedang menyusun skripsi Jurusan Psikologi Universitas Negeri Semarang serta berpikir positif dan efikasi diri akademik pada mahasiswa pada katagori tinggi.

Kemampuan berpikir positif sangat diperlukan dalam diri siswa karena dengan menanamkan berpikir positif akan membantu siswa dalam melihat segala sesuatu kearah yang baik, namun pada kenyataannya masih banyak siswa belum dapat mengoptimalkan berpikir positif dalam dirinya sehingga sering merasa ketakutan akan kegagalan dalam tindakan atau usaha yang dilakukannya. Maka dari itu peran efikasi diperlukan dalam diri siswa agar siswa mampu mengoptimalkan berpikir positif dalam dirinya. Keyakinan diri seseorang mengenai kemampuan atau kecakapannya untuk melakukan tugas akademik yang diberikan disebut efikasi diri akademik. Pada awal kegiatan pembelajaran, masingmasing siswa mempunyai tingkat keyakinan dan kemampuan yang berbeda. Perbedaan tingkat keyakinan tersebut berdasarkan pengalaman sebelumnya misalnya pemahaman materi pelajaran sebelumnya, tingkat kecerdasannya dan sikapnya dalam mengikuti kegiatan pembelajaran. Siswa yang mempunyai efikasi diri yang baik akan berhasil dalam kegiatan belajarnya dan dapat melakukan tugas-tugas akademiknya dengan lancar. Ketika siswa berhasil dalam akademiknya maka dengan begitu akan mampu meningkatkan kemampuan berpikir positif pada diri siswa.

Berdasarkan temuan penelitian tersebut maka dapat disimpulkan bahwa siswa yang memiliki efikasi diri yang baik akan mampu meningkatkan kemampuan berpikir positif pada diri siswa.

\section{Pengaruh Tidak Langsung Efikasi Diri (Self Efficacy) Terhadap Pemecahan Masalah Matematika Melalui Berpikir Positif}

Temuan penelitian menunjukan $t_{h}>t_{t}(41,437>2,000)$, hal ini menunjukan bahwa terdapat pengaruh tidak langsung efikasi diri terhadap pemecahan masalah matematika melalui berpikir positif.

Dilihat dari hasil temuan, kemampuan pemecahan masalah matematika merupakan variabel yang sangat rentan terhadap perubahan. Pemecaahan masalah matematika tidak hanya dipengaruhi oleh factor ekstern siswa tetapi juga dipengaruhi factor intern. Salah satu faktor intern yang cukup berperan dalam peningkatan kemampuan pemecahan masalah matematika siswa adalah efikasi diri (self efficacy) dan berpikir positif. Dalam penelitian ini di dapatkan hasil kemampuan pemecahan masalah matematika dipengaruhi oleh efikasi diri melalui berpikir positif, dengan kata lain kemampuan berpikir positif diperlukan siswa untuk menentukan efikasi diri yang tinggi atau rendah yang akan muncul pada siswa dalam mempengaruhi kemampuan pemecahan masalah matematika.

Pada awal kegiatan pembelajaran, masing-masing siswa mempunyai tingkat keyakinan dan kemampuan yang berbeda. Perbedaan tingkat keyakinan tersebut berdasarkan pengalaman sebelumnya misalnya pemahaman materi pelajaran sebelumnya, tingkat kecerdasannya dan sikapnya dalam mengikuti kegiatan pembelajaran. Siswa yang mempunyai efikasi diri yang baik akan berhasil dalam kegiatan belajarnya dan dapat melakukan tugas-tugas akademiknya dengan lancar begitupun sebaliknya jika efikasi diri yang dimiliki siswa rendah maka siswa tidak akan berhasil dalam kegiatan belajarnya. Sehingga diperlukannya keyakinan berpikir positif dalam diri siswa untuk membantu mencapai kemampuan pemecahan masalah matematika sesuai yang diharapkan. Kebiasaan berpikir positif berperanan penting dalam pengembangan kepribadian yaitu rasa percaya diri, dengan selalu berpikir positif yang akan menimbulkan rasa percaya diri maka ketika siswa gagal dalam pencapaian pemecahan masalah matematika siswa tidak langsung berpikir negative dan mampu bangkit kembali. 
Berdasarkan temuan penelitian tersebut maka dapat disimpulkan bahwa berpikir positif diperlukan siswa dalam membangkitkan efikasi diri yang tinggi pada diri siswa agar meningkatkan kemampuan pemecahan masalah.

\section{PENUTUP}

\section{Simpulan}

1. Terdapat pengaruh langsung yang signifikan efikasi diri (self efficacy) terhadap pemecahan masalah matematika terlihat dari koefisien korelasi antara $X_{I}$ dan $X_{3}$ sebesar 0,983 dan koefisien pengaruh $\mathrm{p}_{31}=0,182$. Untuk $\alpha=0,05$ dan $d k=n-$ $k-1=60-2-1=57$ pada uji dua pihak diperoleh nilai $\mathrm{t}_{\text {tabel }}=\mathrm{t}_{\mathrm{t}}=2,000$.Karena nilai $t_{h}>t_{t}(2,719>2,000)$ yang berarti terdapat pengaruh langsung efikasi diri (self efficacy) terhadap kemampuan pemecahan masalah matematika.

2. Terdapat pengaruh langsung yang signifikan berpikir positif terhadap pemecahan masalah matematika terlihat dari koefisien korelasi antara $X_{2}$ dan $X_{3}$ sebesar 0,993 dan koefisien pengaruh $\mathrm{p}_{32}=0,814$. Untuk $\alpha=0,05$ dan $d k=n-k-1=60-$ $2-1=57$ pada uji dua pihak diperoleh nilai $\mathrm{t}_{\text {tabel }}=\mathrm{t}_{\mathrm{t}}=2,000$. Karena nilai $t_{h}>$ $t_{t}(9,775>2,000)$ yang berarti terdapat terdapat pengaruh langsung berpikir positif terhadap kemampuan pemecahan masalah matematika.

3. Terdapat pengaruh langsung yang signifikan efikasi diri (self efficacy) terhadap berpikir positif terlihat dari koefisien korelasi antara $X_{1}$ dan $X_{2}$ sebesar 0,984 dan koefisien pengaruh $\mathrm{p}_{21}=0,984$. Untuk $\alpha=0,05$ dan $d k=n-k-1=60-1-$ $1=58$ pada uji dua pihak diperoleh nilai $t_{\text {tabel }}=t_{t}=2,000$.Karena nilai $t_{h}>$ $t_{t}(41,437>2,000)$ yang berarti terdapat terdapat pengaruh langsung efikasi diri (self efficacy) terhadap berpikir positif.

4. Terdapat pengaruh tidak langsung yang signifikan antara efikasi diri (self efficacy) terhadap pemecahan masalah matematika melalui berpikir positif dengan berdasarkan $\mathrm{t}_{\text {hitung }}(13,115)>\mathrm{t}_{\text {tabel }}(2,000)$ yang berarti terdapat pengaruh tidak langsung antara efikasi diri (self efficacy) terhadap pemecahan masalah matematika melalui berpikir positif.

\section{Saran} berikut:

Berdasarkan hasil penelitian dan simpulan, dikemukan beberapa saran sebagai

1. Siswa sebagai individu harus berusaha menghargai hidup dan kehidupannya, termasuk potensi yang dimilikinya sehingga dapat memiliki efikasi diri dalam menghadapi tantangan ke depan. Guru, kepala sekolah, orang tua dan masyarakat sebagai orang terdekat siswa juga harus berusaha memberikan penghargaan yang cukup kepada siswa dalam rangka peningkatan kemampuan berpikir positif siswa yang dampaknya akan meningkatkan kemampuan pemecahan masalah matematika siswa.

2. Guru sebagai unsur terdepan dalam proses pembelajaran harus memperhatikan tingkat kemampuan yang ada pada diri siswa salah satunya efikasi diri siswa. Dengan kata lain, guru harus dapat mengarahkan siswa agar mampu mengontrol tingkat efikasi diri siswa pada tingkat yang baik, sehingga dampaknya dapat meningkatkan pemahaman konsep matematika siswa..

3. Siswa dan guru harus mampu mengembangkan suatu suasana pendidikan yang kondusif dimana siswa mampu meningkatkan kemampuan berpikir positif yang pada akhirnya mampu menciptakan efikasi diri yang baik pada diri siswa sehingga berdampak positif terhadap kemampuan pemecahan masalah matematika. 


\section{DAFTAR PUSTAKA}

Alwisol. 2005. Psikologi Kepribadian. Malang: UMM Press

Arifin, Z. 2010. Membangun Kompetensi Pedagogis Guru Matematika. Surabaya: Lentera Cendikia

Baron, R.A. \& Byrne, D. 2003. Social Psychology. Boston: Pearson

Elfiky, I. 2009. Terapi Berpikir Positif. Jakarta: Zaman

Kim, U \& Park Y. 2006. Factor influencing academic achievement in relational cultures: the role of self relational, and collective efficacy. Jurnal Psikologi, 21(6).

Prasetyo, B. \& Haryanto. 2015. Pengaruh model pembelajaran problem based learning (PBL) terhadap kemampuan pemecahan masalah. Dalam Leonard (Editor). EduResearch, Vol. 1. Jakarta: UNINDRA Press.

Adelia, W. 2011. Kehebatan Berpikir Positif. Yogjakarta: Sinar Kejora.

Rachmawati, F. 2015. Hubungan Antara Berpikir Positif Dengan Efikasi Diri Akademik Pada Mahasiswa Yang Sedang Menyusun Skripsi. Skripsi. FKIP, Psikologi, Universitas Negeri Semarang.

Ruseffendi, E.T. 2006. Pengantar kepada Membantu Guru Mengembangkan Kompetensinya dalam Pengajaran Matematika Untuk Meningkatkan CBSA (edisi revisi). Bandung : Tarsito.

Sumarmo, U. Dedy. E dan Rahmat. 2005. Suatu Alternatif Pengajaran Untuk Meningkatkan Pemecahan Masalah Matematika Pada Guru Dan Siswa SMA. Laporan Hasil Penelitian FPMIPA IKIP Bandung

Taylor, S.E.Peplau, L.T. Sears, D.O. 2009. Psikologi Sosial, Edisi Kedua Belas. Jakarta: Kencana 